\title{
Mental Health and Ethical Issues in Cultural and Organizational Change
}

\author{
Marin Dramnescu
}

The Bucharest University of Economic Studies, Bucharest, Romania

\begin{abstract}
Introduction. Human behavior and by extension and organizational behavior becomes intelligible, adaptable and with the possibility of optimization if analyzed from the perspective of development and bio-psychological evolution of the human individual. In his bio-psycho-social evolution, the human individual goes through stages with specific needs, being equipped with specific tools, necessary to satisfy those needs.
\end{abstract}

Purpose. The results of the researches in the field of neurosciences, interpreted in epigenetic and psychological key, offer necessary solutions in the optimization and efficiency of the organizational life. On the other hand, new perspectives open up in understanding interpersonal behavior and relationships, with potential for use in organizational dynamics

Methodology. Each stage of the development of the human brain implies the manifestations of behavior, specific to those stages. The creation of an explanatory model based on the interpretation of the functioning of the human brain and on the analogy between its dynamics and concrete, observable behavior's, deepens the knowledge of the individual on his way to becoming a human being

Results, Discussion and Conclusion. The concepts of Human Being 1.0, 2.0 and 3.0 are closely related to the organization and functioning of the human brain. They describe the type of needs specific to each component level of the brain, needs that determine and motivate human behavior, the rewards associated with their satisfaction, which strengthen behaviors, and the evolutionary hypostasis of human behavior in relation to values and moral principles.

The experimentation of soft skills takes place only by respecting certain conditions that meet the specific needs of employees but especially by ensuring the framework of manifestation of Human being 3.0 through self-control of intention, proactive attitude and building a moral architecture to guarantee its achievement.

\section{Keywords}

Mental Health, Human Being 1.0, 2.0 and 3.0, Values and Moral Principles, System of rewarding, Soft Skills, Ethical reflexes.

Address for correspondence:

Marin Dramnescu, Department of Teachers Training, The Bucharest University of Economic

Studies, Bucharest, Romania. e-mail: aurel.dramnescu@dppd.ase.ro

This work is licensed under a Creative Commons Attribution-

NonCommercial 4.0 International License (CC BY-NC 4.0).

\section{(c) (7) (8)}

(C) Copyright: Dramnescu, 2020

Submitted for publication: 21 July 2020

Received: 21 July 2020

Accepted for publication: 02 November 2020

Licensee NDSAN (MFC- Coordinator of the NDSAN), Italy

DOI http://doi.org/10.32437/mhgci.v4i2.97 


\section{Introduction}

Focusing management on people, on the human resources available to an organization, is a normal fact. The Human Centered Management (HCM) paradigm is basically a propitious philosophy of returning to normal, to balance, to efficiency, to the efficient and motivating phrase of win-win.

In its broadest sense, management involves a process by which an organization travels from $A$ to $B$, where $A$ is the current state, present, experienced and $\mathrm{B}$ is the desirable state, imagined and designed in the hope of becoming a concrete experience. The whole managerial process is presented in the form of a dynamics in which a conglomeration of various resources (human, technical, financial, relational, conjectural, etc.) is articulated more or less logically, rationally and emotionally alike and which makes the strategies, goals, objectives and tactics, previously designed, to become operational, to become finite, concrete experiences.

The managerial process must be characterized by balance and mutual support between resources, realism in design and pragmatism in progress. Of all the resources involved in the good functioning of the management, the human resource is and will remain the most unpredictable variable, being at the same time the "problem link" of the entire managerial chain. Moreover, the very cataloging of individuals involved in the organization as a "human resource" is debatable because it puts the equal sign between human being and other non-human organizational, instrumental resources or those of organizational infrastructure.

As a whole, an organization is a human creation based on people and dependent on people. Well, people are the ones who make the organization possible, they are the ones who make it productive, efficient, competitive or sustainable.

Well, the people who make it up are the ones who make sense of it. And they, the people, through their attitudes and actions are the ones who make it unproductive, inefficient, maladapted and unsustainable. In their absence, the organization, in all its complexity, with all its exceptional management and all its projections of becoming, is sterile, non-animated, dead.

The vision in which the organization is superordinate to human being, independent of him and of whose abilities and competences it disposes many times, to his detriment, is unnatural, artificial and for itself. This direction, this trend of evolution and growth of the organization will not go unnoticed. It is felt, understood and aware of the "human resource" that will eventually react through various attitudes and behaviors ranging from resignation, apathy, noninvolvement, and superficiality of individual or collective action, to rejection, revolt, insubordination or institutional divorce.

HCM's vision is about balance and - especially - about the rendering of human humanity, as a fundamental agent and creator of the meaning of an organization. In the organizational context, human being is aware of himself, of his status, role and importance in the common becoming of the human being-organization binomial, of the fact that the organization is not subordinated to him and is not independent of him but represents a form of existence created by him or a favorable experiential framework, which ensures the fulfillment of personal needs. Such an understanding presupposes that each individual becomes the center of his organization and makes it a multicenter life circumstance, from which each - both the human being and the organization obtain benefits and satisfactions.

$\mathrm{HCM}$, through its principles, draws attention to the fact that the efficiency of any type of management that, in achieving its goals, involves the cooperation and coordination of people is dependent on the well-being it provides them in their organizational action. (Lepeley, 2017).

If for the organization, the finality of achieving the desired and planned state is the profit, for the people involved in achieving the organizational desideratum, the finalities are diverse, different, more or less expressed in visible or useful profit to the organization.

People are extremely involved and efficient in achieving the goals of the organization only if through them are achieved personal goals, needs and meanings that belong to them and that are often extra-organizational.

The balance that HCM proposes and supports is the win-win one: that is, the organization makes a profit, is competitive, is sustainable, has honest and creative growth and expansion prospects and the people who "make all this possible" feel good. "doing all this." They grow and develop individually in an organizational context, and often in directions independent of the organization but with a decisive impact on its development. 


\section{Purpose}

The results of the researches in the field of neurosciences, interpreted in epigenetic and psychological key, offer necessary solutions in the optimization and efficiency of the organizational life. On the other hand, new perspectives open up in understanding interpersonal behavior and relationships, with potential for use in organizational dynamics.

\section{Methodology}

Each stage of the development of the human brain implies the manifestations of behavior, specific to those stages. The creation of an explanatory model based on the interpretation of the functioning of the human brain and on the analogy between its dynamics and concrete, observable behavior's, deepens the knowledge of the individual on his way to becoming a human being.

\section{Results and Discussion}

\section{Organizational needs vs. individual needs}

The people who make up an organization, i.e. "human resources", "employees", "human capital", "labor force" or "employees", regardless of the name we give them, are the success or disaster of an organization. Organizational efficiency depends on their willingness to get involved in the organization through their organizational role and the responsibility with which they perform their professional tasks. Expressions such as: "the manager must increase employee motivation," "the manager must instill confidence in employees", "the manager must improve the organizational culture", etc. were, are and remain simple statements in the absence of their translation into experience, action or finite fact. Of course, the manager "has to ..." a lot. But everything that the manager "must ..." is part of his role and belongs to his organizational status. Just as many other "must ..." are assigned to another employee, in accordance with their organizational status and role.

The manager of an organization is an element of the "human resource", is part of it and has its attributes. He is not placed above it; he is not broken by it and he is not a separate part of it by virtue of its organizational status. Organizational statuses are equal in terms of respect, dignity and fair, non-discriminatory treatment, granted a priori. They differ from each other only by the complexity of the associated role and by the responsibility required in the exercise of that role. Moreover, the understanding of this idea and its application make it possible to validate and apply the HCM principle according to which the wellbeing of people is central to Human Centered Management and human centered of organizations.

The efficiency of an organization is dependent on the responsible assumption of organizational roles while the exercise of roles is dependent, on the one hand, on qualifications, professional experience and skills, and on the other hand on the intentions and attitudes of the people who assume those roles.

Beyond his organizational status and beyond the role he has in an organization, the employee is primarily a person with multiple needs that he hopes to meet in terms of the work he does, while performing professional tasks, frequently using them for their own benefit and to the detriment of the objectives of the organization.

In order for the employee's attitude to be as positive as possible and in accordance with the organizational goals and for his involvement in the life of the organization to be as complete and efficient as possible, managerial actions must satisfy as many of the needs of employees or at least those who lead or foreshadows a state of well-being, of satisfaction acceptable to as many of them as possible.

The task of management to be focused on the needs of the staff is difficult because due to their multitude and variety, the individual needs of all will never be able to be met without being, in one way or another, affected the efficiency of the organization.

The way in which HCM could solve this dilemma in the most efficient way refers to the education of employees and, in particular, to the creation of contexts through which they can practice those personality traits generically reunited under the name of soft skills. Organizations, regardless of their nature, must become true units of education, specialized in lifelong learning. From this perspective, $\mathrm{HCM}$ has a pronounced psychological, formativeeducational character. For the success of HCM, understanding the psycho-social development of the individual is essential because he will develop behaviors convergent to organizational goals only to the extent that he understands, feels and wants this. Corroborating and synchronizing the needs of the organization with the needs of individuals and satisfying all of them in an acceptable manner and assumed by both parties, can lead to effective management. 
Human behavior and by extension and organizational behavior becomes intelligible, adaptable and with the possibility of optimization if analyzed from the perspective of development and bio-psychological evolution of the human individual. In his bio-psycho-social evolution, the human individual goes through stages with specific needs, being equipped with specific tools, necessary to satisfy those needs.

The needs of the individual are varied, with different intensities and degrees of imperativeness. From this perspective, understanding the dynamics of human needs and how they can become motivational resources or elements of optimization and vectorization of organizational behavior can be a distinct concern of HCM.
The evolution of organizations and the type of management cannot ignore the way of designing and functioning of the human individual, they constantly adapting to his needs.

In fact, the people created the organizations and implemented the specific management according to his needs. This vectorization, this evolutionary and interactive dynamics has effects of formation, transformation and perpetual restructuring of the two actors - Human being and Organization - confirming that the human being will not be the same after the implementation of new forms of management, and the management of organizations, in its turn, will not be static but it will adapt and create itself according to the satisfaction of the increasingly complex and elaborate needs of human being.

Table 1 Comparisons between the evolution of the individual and the organizations

\begin{tabular}{|c|c|c|c|c|c|}
\hline $\begin{array}{c}\text { Human being } \\
1.0\end{array}$ & $\begin{array}{c}\text { Organization } \\
1.0\end{array}$ & $\begin{array}{c}\text { Human } \\
\text { being } 2.0\end{array}$ & $\begin{array}{c}\text { Organization } \\
\mathbf{2 . 0}\end{array}$ & $\begin{array}{c}\text { Human being } \\
\mathbf{3 . 0}\end{array}$ & $\begin{array}{c}\text { Organization } \\
\mathbf{3 . 0}\end{array}$ \\
\hline To be & Group & To have & Organization & To do & $\begin{array}{c}\text { Semantic } \\
\text { Organization }\end{array}$ \\
\hline $\begin{array}{l}\text { Unconditional } \\
\text { reflexes }\end{array}$ & $\begin{array}{c}\text { Empirical } \\
\text { management }\end{array}$ & $\begin{array}{l}\text { Conditional } \\
\text { reflexes }\end{array}$ & $\begin{array}{c}\text { Organizational } \\
\text { management }\end{array}$ & $\begin{array}{l}\text { Ethical } \\
\text { reflexes }\end{array}$ & $\begin{array}{c}\text { Human } \\
\text { Centered } \\
\text { Management }\end{array}$ \\
\hline $\begin{array}{l}\text { Information } \\
\text { Reaction }\end{array}$ & $\begin{array}{c}\text { Reaction } \\
\text { oriented }\end{array}$ & $\begin{array}{c}\text { Action } \\
\text { Experience }\end{array}$ & Task-oriented & $\begin{array}{l}\text { Control, Self- } \\
\text { control }\end{array}$ & $\begin{array}{l}\text { People- } \\
\text { oriented }\end{array}$ \\
\hline Amoral & $\begin{array}{l}\text { Impulsive } \\
\text { Reactive }\end{array}$ & Immoral & $\begin{array}{c}\text { Control } \\
\text { Procedures }\end{array}$ & Moral & $\begin{array}{c}\text { Self-control } \\
\text { Self-education }\end{array}$ \\
\hline Individualization & $\begin{array}{c}\text { Random } \\
\text { interactions }\end{array}$ & Socialization & $\begin{array}{c}\text { Multiple } \\
\text { connections }\end{array}$ & $\begin{array}{l}\text { Intention } \\
\text { control }\end{array}$ & $\begin{array}{l}\text { Continuing } \\
\text { education and } \\
\text { training unit }\end{array}$ \\
\hline $\begin{array}{l}\text { Consumes } \\
\text { content }\end{array}$ & $\begin{array}{l}\text { Static } \\
\text { content }\end{array}$ & $\begin{array}{l}\text { Distributes } \\
\text { content }\end{array}$ & $\begin{array}{l}\text { Shared } \\
\text { content }\end{array}$ & $\begin{array}{l}\text { Crea } \\
\text { cont }\end{array}$ & $\begin{array}{l}\text { Connected } \\
\text { content }\end{array}$ \\
\hline Basic needs & $\begin{array}{l}\text { Information } \\
\text { sharing }\end{array}$ & $\begin{array}{l}\text { Superior } \\
\text { needs }\end{array}$ & Interaction & $\begin{array}{l}\text { Need for } \\
\text { meaning }\end{array}$ & $\begin{array}{l}\text { Professional } \\
\text { self- } \\
\text { fulfillment }\end{array}$ \\
\hline $\begin{array}{c}\text { Emotion } \\
\text { Satisfaction }\end{array}$ & $\begin{array}{c}\text { Experimentatio } \\
\mathrm{n}\end{array}$ & $\begin{array}{c}\text { Feeling } \\
\text { Contentment }\end{array}$ & Hard Skills & $\begin{array}{c}\text { Passion } \\
\text { Well-being }\end{array}$ & Soft Skills \\
\hline $\begin{array}{l}\text { Selfishness, } \\
\text { Egocentrism }\end{array}$ & Subsistence & $\begin{array}{c}\text { Sociable } \\
\text { Experiential }\end{array}$ & Profit & $\begin{array}{c}\text { Meanings } \\
\text { Personal sense }\end{array}$ & $\begin{array}{c}\text { Meanings } \\
\text { Collective } \\
\text { sense }\end{array}$ \\
\hline $\begin{array}{c}\text { Survival } \\
\text { Conservation } \\
\text { Protection }\end{array}$ & $\begin{array}{l}\text { Connects } \\
\text { information }\end{array}$ & $\begin{array}{l}\text { Adaptation } \\
\text { Integration } \\
\text { Recognition }\end{array}$ & $\begin{array}{l}\text { Connects } \\
\text { people }\end{array}$ & $\begin{array}{l}\text { Becoming } \\
\text { Creativity } \\
\text { Ethical } \\
\text { conduct }\end{array}$ & $\begin{array}{l}\text { Connects } \\
\text { content, } \\
\text { context, and } \\
\text { knowledge }\end{array}$ \\
\hline
\end{tabular}




\section{$\mathrm{HCM}$ and human resource knowledge}

The concepts of Human Being 1.0, 2.0 and 3.0 are closely related to the organization and functioning of the human brain. They describe the type of needs specific to each component level of the brain, needs that determine and motivate human behavior, the rewards associated with their satisfaction, which strengthen behaviors, and the evolutionary hypostasis of human behavior in relation to values and moral principles.

The human brain consists of three major components or its functioning includes three basic levels: a level called archaic or reptilian brain (reticular system, cerebellum, basal ganglia and brainstem), another level called emotional brain or limbic system (amygdala, hypothalamus and thalamus) and finally as a last acquisition, the neocortex or the rational brain. The three components, although they have precise specializations are interdependent and the emergence of their functioning is what can be called human behavior.

The human brain has an advanced system of rewarding the consumption of resources in the process of satisfying various needs. This system is presented as a complex kit of bio-chemical mechanisms through which the human individual is able to associate certain activities or life circumstances with a feeling of pleasure. As a result of this association, there is a tendency to repeat or search in the future for those situations that made those experiences possible.

Thanks to the brain's reward system, discomfort, annoyance, physical or emotional pain and suffering of any kind are avoided, and the whole behavior is oriented towards those activities that can be sources of pleasure. Although the human brain has only one reward system, the way it enhances and makes the individual's subjective experiences feel pleasant is differentiated according to the level to which it is addressed: reptilian, emotional or rational. This mode of operation and differentiated reward makes what is experienced as pleasure have different nuances, interpretations and intensities, depending on the type of need met, the effort made and the complexity of the behavior manifested.

In an organization, the more the rational brain is involved in meeting its own specific needs, the stronger, more invasive, generalized and more complete the emotional benefit of living is, and the more assumed and responsible the employee's future involvement is.
Table 2 The bio-psychological organization of the human brain

\begin{tabular}{|c|c|c|}
\hline Reptilian brain & Emotional brain & Rational brain \\
\hline Survival & Adaptation & Becoming \\
\hline Unconditional reflexes & Conditional reflexes & Ethical reflexes \\
\hline Automatic / Amoral & Automatic / Immoral & Intentional / Moral \\
\hline Aptitude potential & Hard Skills & Soft Skills \\
\hline Reward system 1.0 & Reward system 2.0 & Reward system 3.0 \\
\hline Satisfaction & Contentment & $\begin{array}{c}\text { Well-being / } \\
\text { Happiness }\end{array}$ \\
\hline Condition: to be & Condition: to have & Condition: to do \\
\hline Human being 1.0 & Human being 2.0 & Human being 3.0 \\
\hline
\end{tabular}

The development of the brain is presented as a gradual process with evolution from simple and automatic to complex and intentional. Thus, if we are born equipped with a complex system of unconditional reflexes necessary for survival (osteotendinous, masticatory, section, lacrimal, auditory-oculogir, salivation, pupil, photomotor, etc.) the evolution forces us to form conditional reflexes necessary to adapt to the environment (reading, writing, walking, speaking, automation and professional skills). But survival and adaptation are insufficient for becoming human, which implies a new set of reflexes, of a higher type that we could call ethical reflexes necessary to experience the human condition. (Dramnescu et al., 2020)

Unconditional reflexes are innate. With their help, survival and orientation in the environment are ensured. They manifest themselves in the form of simple answers, short-lived and always in the same way. They are usually inherited, species-specific and are constant throughout life. They are automatic and therefore involuntary and unconscious and have no value coloration. In other words, unconditional reflexes are amoral.

Conditional reflexes are tools that make it possible to integrate, control, internalize and enhance the environment and adapt to it. Repeated experiences, skills, increasingly varied and flexible automation optimize the necessary voluntary effort, ensuring the production of infinite efficient experiences. They are automatic but, unlike unconditional reflexes, they can be made aware. As a result of their awareness, they can also be analyzed through voluntary effort, they can be corrected, improved or adapted to the new environmental conditions.

Ethical reflexes are automatisms that intervene as a regulatory factor of action in its intentional

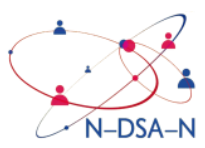


phase. The automatism of an ethical reflex consists in the fact that it is triggered, made present and acted before a decision is made, more or less intellectually elaborated and can modulate the intention in the sense of adapting it to moral principles or at least an approximation of them as faithfully as possible. Once activated, the ethical reflex becomes fully conscious and problematic, directing the intention through the filter of the individual's moral consciousness. As a result, the modulation of the intention in accordance with the moral conscience of the individual, will determine an action resulting from his free will and from his duty to act morally. (Dramnescu et al., 2020)

An ethical reflex has two directions of manifestation: to modulate the action by influencing the intention that triggers that action and to satisfy the need for meaning that ensures the becoming of the individual. By the becoming of the individual is meant an optimal relationship between what he feels and what he has to do in such a way as to ensure the maximum valorization of the environmental opportunities and of his bio-psychological potential.

For example, when we want to do a business, regardless of its nature, the conditional reflex vectorizes our entire psycho-intellectual behavior to maximize our profit or benefits obtained even to the detriment of the interlocutor. The need to adapt through the type 2.0 reward takes precedence, respectively to be satisfied with the business done. The primary intention is selfcentered, selfish, individualistic, self-syntonic, and often unethical.

An ethical reflex is activated before a decision is made that has immoral components in itself and regulates or tempers the action to be taken by appealing to moral values or conduct. As a result of this intervention, the effect is to adapt or correct the intention and to initiate an action different from the one originally designed. (Dramnescu et al., 2020)

Intentions are adjusted, corrected or adapted to moral principles through training, perseverance and repeatability becoming automatisms. In similar situations or in other life circumstances that require the decision on a future action, ethical reflexes, as regulatory mechanisms, become natural and lead to behaviors observable by others.

Their feedback results in a new series of experiences that make the well-being more extensive in terms of durability, easier to repeat and faster in terms of frequency of experience.
Ethical reflexes are those that ensure this modus vivendi, similar to conditioned reflexes that make possible the best possible adaptation to the environment and to ourselves or unconditional reflexes that are impeccable in their role of protection and survival.

The formation of these reflexes is in turn related to the satisfaction of the fundamental need of the human individual to develop and build himself, to make sense, regardless of the type of social organization, culture or traditions. (Dramnescu et al., 2020)

Forgiveness, prudence, tolerance, altruism, compassion, or generosity, for example, cannot remain only at the level of concept or isolated experiment. They are not simple ethical recommendations or philosophical values to which we tend, but they must become automatisms through learning, practice and internalization. Critical thinking, teamwork, professional responsibility, openness to the new, cognitive flexibility are more than just skills. Soft skills must become personality traits of employees through continuous experimentation. The organization through its management has the duty to create frameworks for learning, training, experimentation, encouragement and evaluation of these behaviors.

The well-being of the individual and the favorable and stimulating atmosphere of an organization cannot be experienced in the absence of these ethical reflexes. We survive with great difficulty and in very special conditions in the absence of the masticatory reflex, for example. We adapt with great difficulty and many constraints in the absence of the ability to walk or speak. (Dramnescu et al., 2020)

Likewise, we are limited in reaching our potential in the absence of ethical reflexes. At this level we can talk about the ethical dimension of soft skills. Attachment and responsibility to the organization is an emerging effect of the correlated and complete functioning of all these reflexes.

The knowledge of the general profile and of the pattern of manifestation of the hypostases of the individual according to his evolutionary specificities is constituted as strong points for HCM. Based on these profiles, appropriate and adapted management strategies can be imagined and adapted, both individual and collective, through which organizational goals can be harmonized with employee responsibility, both under the dome of well-being and a positive, stimulating and creative organizational atmosphere. (Dramnescu et al., 2020) 


\section{Human being 1.0. The reptilian brain and immediate satisfaction}

Table 3. Bio-psychological characteristics of the reptilian brain

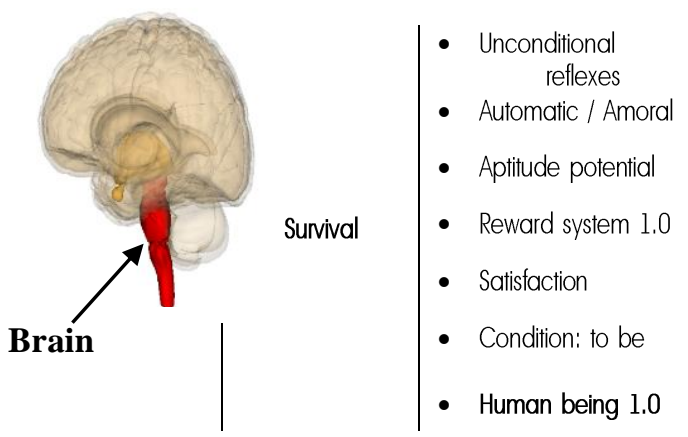

The reptilian brain through the information it has and the mechanisms available to it ensures the durability and sustainability of the body, i.e. the survival of the individual becomes possible through the control it has over the basic functions of the body such as relationship, nutrition and reproduction. .

Also, unconditional reflexes are characteristic of the functioning of the reptilian brain. The reptilian brain is responsible for maintaining and perfecting the vital processes, ensuring security as an individual and perpetuating the species. In special, crisis situations, when the survival of the individual is more or less threatened or when environmental stimuli are interpreted as physical insecurity or emotional instability, deprivation of food, sleep, sensory information, major changes in the life of the individual, upon contact with the new, with physical or emotional pain, it sets in motion resources and reflexes that cancel out the activity of the rational brain, imposing itself on behavior. Depending on the context, and the assessment of the danger, it generates reactions of violence, aggression or strategies of abandonment and withdrawal ("fight or flight") characteristic of the individual in extreme situations.

As all of these escape conscious control, they have no value coloration. They are amoral and as a result do not fit into the conditions of moral behavior.

The specific condition experienced at this level, as a result of fulfilling various needs is that offered by the Reward System 1.0, characterized by immediate satisfaction obtained imperatively and with minimal voluntary effort. (Dramnescu, 2020)

The well-obtained and consumed states after balancing immediate needs are volatile, intense, short-lived and usually disappear immediately after a need has been met.

Human being 1.0 is focused on getting immediate benefits in the easiest way possible. He usually sets short-term goals and is less concerned about the consequences of his behavior. At the level of Human being 1.0, in general, his concerns are related to the state of being and the functioning of the reptilian brain describes the general behavior of Man1.0.

Human being 1.0 is not an outdated and outdated evolutionary version. He is extremely present in every moment of the individual's life, constantly asking for physical, emotional or cognitive resources to satisfy his own needs.

Managerial recommendations: organizational stability and predictability; physical and mental safety related to the workplace; procedural coherence and transparency.

\section{Human being 2.0. The emotional brain and the comfort of self-satisfaction}

Table 4. Bio-psychological characteristics of the emotional brain

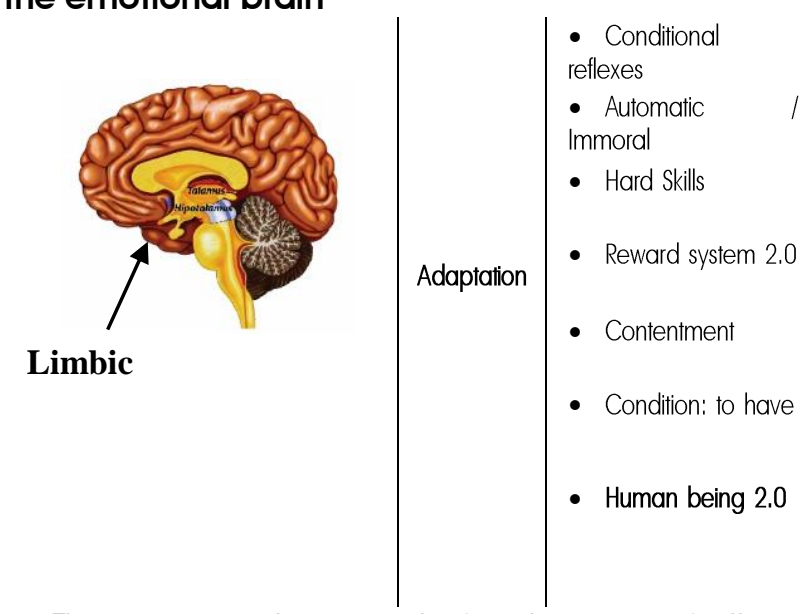

The organization and functioning of the emotional brain define the way of being of Human being 2.0. Once survival is ensured in what is essential, adaptation to the environment becomes the main direction and concern of Human being 2.0., possible with the help of conditional reflexes.

The effective adaptation to the VUCA (volatility, uncertainty, complexity and ambiguity) environment involves behaviors that include and extend the specific behaviors of Human being 1.0

Human being 2.0 is torn between the sometimes imperative, imposed and unavoidable demands, sometimes painful, torturous, tumultuous and extremely difficult to refuse, coming from the reptilian brain and the 
constraints, seduction and superior rewards offered by the rational brain. (Dramnescu, 2020)

In addition to all this, the task of Human being 2.0 is to satisfy higher than basic needs, whose needs facilitate the adaptation to the environment and the psychological balance of the individual: the need for belonging, recognition, knowledge and self-knowledge, the need for beauty, esteem and status.

Here we meet the need to have unnaturally placed before that of to be. Human being 2.0 knows and thinks he is only if he has. This accumulation of goods, emotions, relationships, money, feelings, recognition, admiration, etc. creates the illusion of meaning, being and authenticity. I have, so I am! is the motto of Human being 2.0 .

Human being 2.0 victimizes himself. Obviously, he often does so for hypocritical and immoral reasons. $\mathrm{He}$ is the one who declares that the organization in which he is involved does not value him, that his money is never enough, that he is not respected enough at work. All these statements, as a rule, have nothing true in them or have very little, but they are perverted manifestations by which he demands something and obtains that something with minimal or absent effort. And not infrequently his intention is selfish and unethical as he is often aware of this fact.

The dissatisfaction of Human being 2.0 translates into noise. Lots of relational, attitudinal, and emotional noise. Lots of intellectual noise and a lot of exhibitionism. The Human being 2.0 is noisy, he always asks for something, he complains to everyone, he cries for pity, he victimizes himself, he has the courage, he gets angry quickly, he is naughty. Nothing he has is enough. Not enough money, not enough holidays, not enough love, not enough recognition, not enough time. If it is enough, it becomes boring, if it is boring then he wants something else, if he gets that something else, it will be either insufficient or not necessary. As a result, he shows his suffering and blames his destiny, but he does not do it in a serious, categorical and definitive way, but only in order not to give up his automatisms, his habits and beliefs. (Dramnescu, 2020)

He complains about the lack of solutions, the lack of help, the lack of support, but he prefers not to change anything in the present way in which he satisfies his needs.

Here we find the background of the moral relativism of Human being 2.0. In his preference for convenience, in his somewhat justified conservatism and in his permanent inclination towards moral compromise in achieving his goals.

Although the state of emptiness of soul, of absence of meaning and fulfillment accompanies Human being 2.0 throughout life, he is the one who makes it possible to experience it. Human being 2.0 is the experiential individual who gives flavor to life, who makes it possible by translating it into finite experience, despite all the compromises, slips and inconsistencies that are attributable to him.

Managerial recommendations: relational comfort horizontally and vertically; encouraging individual expression and initiatives; personalized reward; non-discriminatory and relevant framework as important for each organizational role.

\section{Human being 3.0. The rational brain and the experiencing of well-being}

Table 5. Bio-psychological characteristics of the rational brain

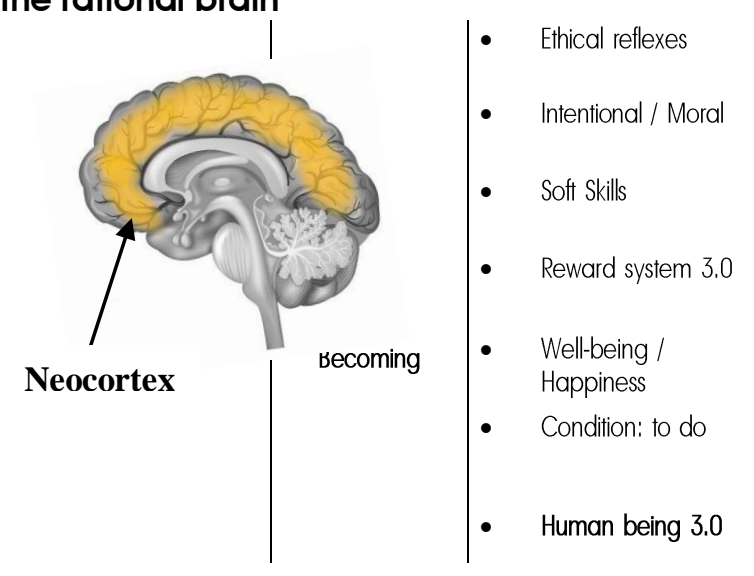

From an ontogenetic perspective, the higher level in brain development is represented by the cerebral cortex, also called the rational brain because it is responsible for the intellectual, cognitive, logical and rational thinking functions. To read, to write, to know, to assimilate information, to give them meanings, in a word, to create, are natural behaviors, specific to it. Soft skills such as: solving complex problems, critical thinking, coordination with others, decision making or cognitive flexibility are encountered at this level.

The prefrontal cortex fulfills the role of absolute coordinator that it does not negotiate with anyone. It is the one which sets goals, organizes and plans a variety of activities, is involved in solving complex life problems and ensures the most effective relationship with the lower and 
subordinate courts, the limbic system and the reptilian brain, coordinating their functioning, activity and behavior through a complex series of concessions, compromises, impositions, constraints, limits, rewards, incentives, motivations, waivers or justifications. But the essential role of the neocortex is to create. (Dramnescu, 2020)

These perpetual negotiations, proposals and resettlement in decision-making always produce new experiences, lived subjectively as authentic experiences, associated with unique chemistry that will generate unique feelings. New felt and lived experiences stimulate brain connectivity causing the construction or formation of new neural networks while the least used or not used are abandoned. Consistent use of new networks, through repetition, strengthen, become more myelinated and wider, with greater information transport capabilities.

As they become more and more used, they will come under the control of the limbic system as conditional reflexes or as already validated schemes that will be requested, defended, consolidated whenever they are threatened with destructuring or abandonment. On this logic, the effort to be moral in time creates the habit of being moral or a style of being that has the underlying imprint of morality.

Human being 1.0 and Human being 2.0 develop and manifest in direct relation to survival because adaptation also takes place in order to ensure survival, in the end. Instead, Human being 3.0, represented by the neocortex, cannot exist and can only develop in relation to others. This draws attention to the enormous importance of interpersonal relationships and cooperation with others. The organization, through $\mathrm{HCM}$, can play this role of continuous formation of Human being 3.0 by developing his becoming by equipping him with ethical reflexes. The formation of ethical reflexes lays the foundations and creates the conditions for the formation and strengthening of soft skills. In the absence of ethical reflexes, soft skills that should be true personality traits or invariants of it, are inoperative or become simple skills used in a false ethical behavior, superficial and caricatured. Ethical reflexes are specific to Human being 3.0. (Dramnescu, 2020)
Managerial recommendations: intellectual stimulation; involvement in solving organizational problems; autonomy adapted to the social role and independence in decision making.

\section{Conclusion}

The authentic, efficient, and meaningful management for an organization is the one that focuses on people, explains them, encourages them and motivates them to do what is ethical and beneficial for an organization. (Yukl, 2010)

The knowledge of the human resource is not limited only to the organizational management procedures but must be extended by taking over interdisciplinary explanatory models or from the neurocognitive, philosophical or pedagogical fields.

The experimentation of soft skills takes place only by respecting certain conditions that meet the specific needs of employees but especially by ensuring the framework of manifestation of Human being 3.0 through self-control of intention, proactive attitude and building a moral architecture to guarantee its achievement.

The ethical dimension of soft skills ensures the development and efficiency framework of the organization 3.0.

\section{Conflict of interest}

The author declares that he has no conflict of interests.

\section{References}

Dramnescu, M. (2020) Voința de fericire. (The will to happiness). Paideia. București.

Dramnescu, M., Dumitru, D., Lacatus, M.L., Camelia S., (2020). Ethical dimensions of soft skills Journal of Business Ethics (submitted manuscript)

Lepeley, M.T. (2017) Human Centered Management. The 5 Pillars of Organizational Quality and Global Sustainability, Routledge.

Yukl, Gary A. (2010). Leadership in organizations. 7th Edition, Upper Saddle River, NJ: Prentice Hall 